\title{
Green Supply Chain: Studi Keterkaitannya dengan Kinerja Lingkungan dan Kinerja Finansial
}

\author{
Ayu Rohdayatin, Pudjo Sugito, Krisnawuri Handayani* \\ Fakultas Ekonomi dan Bisnis,Universitas Merdeka Malang, Malang \\ * krisnawurihandayani@gmail.com
}

\begin{abstract}
This study aims to analyze the linkage of green supply chain management, environmental performance and finansial performance. The research population are all restaurants in Malang with propotional random sampling as sampling technique. Primary data analysis technique using Partial Least Square (PLS). The result shows :1) green supply chain effect on finansial performance, 2) green supply chain effect on to environmental performance, 3) environmental performance has no effect to finansial performance, and 4) environmental performance does not mediate the influence of green supply chain to finansial performance. It means, green supply chain is very important to improve finansial performance, but environmental performance has not become a mediator in improving finansial performance at restaurant business in Malang.
\end{abstract}

Keywords: Environmental Performance, Finansial Performance, Green Supply Chain.

\section{PENDAHULUAN}

Pertumbuhan ekonomi yang pesat dan ekspansi industri besar-besaran membuat manusia cenderung menguras dan menggunakan sumber daya alam lebih tinggi dari sebelumnya. Pada saat yang bersamaan pembangunan dan polusi yang dihasilkannya menyebabkan kerusakan yang sangat besar pada lingkungan hidup yang kemudian dapat merusak ekologi (Fleury \& Davies, 2012). Pencemaran lingkungan merupakan masalah utama yang memiliki potensi untuk mengakibatkan kepunahan makhluk hidup dibumi jika tidak segera diatasi. Beberapa sektor yang terus tumbuh dan menjadi penyumbang turunnya kualitas lingkungan dunia adalah proses industri, transportasi, limbah, produk pertanian, power stations, penggunaan lahan dan biogass burning, fossil fuel, perumahan, pariwisata dan lainlain. Setiap perusahaan tidak dapat mengabaikan begitu saja isu lingkungan ini, tetapi harus bertanggung jawab terhadap limbah yang dihasilkan sehingga dapat mengurangi pencemaran lingkungan. Perusahaan yang peduli terhadap lingkungannya akan berdampak pada kesadaran yang tinggi dari konsumen sehingga mengakibatkan tingkat persaingan di pasar tidak lagi berorientasi pada mutu, harga dan pengiriman tetapi isu lingkungan. Hal ini tentunya perlu mendapatkan perhatian serius dari perusahaan untuk mengelolah suatu rantai pasok.

Rantai pasok adalah sebagai jejarng seluruh organisasi mulai dari pemasok sampai ke pengguna akhir dan aktivitas yang berhubungan dengan aliran dan transformasi dari barang, informasi dan uang (Handfield \& Nichols, 2002). Sedangkan Manajemen Rantai Pasok (Supply Chain Management) merupakan pengintegrasian proses bisnis 
berupa kolaborasi antara mitra rantai pasok dalam menyediakan produk, jasa, dan informasi untuk meningkatkan kinerja perusahaan dan memberikan nilai tambah ke pelanggan dan pemangku kepentingan lainnya (Purnomo, 2010). Rantai Pasok terdiri dari lima bagian yaitu bahan baku, industri, distribusi, konsumen, dan limbah. Setiap tautan dalam Rantai Pasok dapat menyebabkan terjadinya polusi, limbah, dan bahaya lain terhadap lingkungan. Mulai dari tahap konsep sampai dengan barang dimusnahkan, selalu terdapat penggunaan sumberdaya secara berlebihan yang mengakibat total ongkos logistik menjadi lebih mahal serta berdampak terhadap kelestarian lingkungan.

Selain perusahaan, industri pariwisata juga memiliki dampak terhadap kelestarian lingkungan yaitu seperti pembuangan sampah sembarangan sehingga menyebabkan bau tidak sedap dan juga membuat tanaman di sekitarnya mati, pembuangan limbah hotel, restoran, dan rumah sakit yang dapat merusak air sungai, danau, dll. Berdasarkan informasi yang diperoleh dari Dinas Pariwisata kota Malang mengenai peningkatan jumlah wisatawan, berdampak positif pada beberapa sektor pariwisata seperti hotel dan restoran. Pertumbuhan hotel dan restoran yang ada di kota Malang setiap tahunnya selalu mengalami peningkatan terutama untuk restoran. Berbagai macam restoran dengan konsep dan menu makanan yang beragam mampu menarik wisatawan mancanegara maupun lokal untuk mampir dan beristirahat sejenak. Menurut Badan Pusat Statistika (BPS) Kota Malang di ketahui bahwa keberadaan restoran selama 3 tahun terakhir mengalami kenaikan. Sayangnya, semakin banyaknya restoran maka semakin besar pula limbah yang dihasilkan. Bagi restoran, sisa makanan merupakan limbah yang memusingkan. Sampah yang umumnya berasal dari dapur, seperti bagian dari sayuran yang tidak termasak, minyak bekas menggoreng, atau sisa-sisa makanan yang tidak habis disantap tamu, merupakan bagian yang terkontribusi terhadap pencemaran lingkungan. Secara umum, yang disebut limbah adalah bahan sisa atau buangan yang dihasilkan oleh suatu proses produksi, baik skala rumah tangga maupun industri dimana kehadirannya tidak dikehendaki karena tidak memiliki nilai ekonomis. Apabila limbah ini dibuang ke lingkungan, dapat menimbulkan dampak negatif. Limbah restoran adalah buangan atau sisa-sisa yang dihasilkan oleh restoran yang dapat berupa sisa-sisa makanan ataupun minuman. Limbah tersebut biasanya hanya dibiarkan atau dibuang begitu saja di penampungan limbah dan tidak diolah kembali sehingga menyebabkan pencemaran lingkungan, tentu saja hal ini dapat merugikan warga atau masyarakat sekitar. Penelitian yang dilakukan pada restoran di Kota Malang mempunyai bertujuan: 1) untuk menganalisis apakah green supply chain management mempunyai pengaruh terhadap kinerja finansial, 2) untuk menganalisis apakah green supply chain management mempunyai pengaruh terhadap kinerja lingkungan, 3) untuk menganalisis apakah kinerja lingkungan mempunyai pengaruh terhadap kinerja finansial, dan 4) untuk menganalisis apakah green supply chain management mempunyai pengaruh secara tidak langsung terhadap kinerja finansial melalui kinerja lingkungan.

Green Supply Chain Management (GSCM) menjadi salah satu strategi yang penting untuk mencapai pembangunan yang berkesinambungan bagi perusahaan (Kurien et al., 2012). Konsep GSCM merupakan manajemen rantai pasokan yang berhubungan dengan aspek lingkungan. Manajemen rantai pasokan yang berbasis green penting untuk diterapkan karena selama ini ukuran kinerja rantai pasokan biasanya tidak memperhatikan dampak terhadap lingkungan. Isu rantai pasokan ramah lingkungan dipandang kritis bagi kesuksesan implementasi ekosistem industrial dan ekologi industrial. Limbah dan emisi yang dikeluarkan oleh rantai pasokan telah menjadi sumber utama masalah lingkungan termasuk diantaranya pemanasan global dan hujan asam (Bloemhof-Ruward et al., 1995). 
Selain itu, tata kelola tersebut juga sebuah inovasi dalam penerapan strategi rantai pasok yang didasarkan dalam konteks lingkungan yang mencakup aktivitasaktivitas seperti reduksi, recycle, reuse dan subsitusi material (Dheeraj \& Vishal, 2012). Konsep GSCM merupakan pengintegrasian perspektif lingkungan ke dalam manajemen rantai pasok mencakup desain produk, pemilihan dan seleksi sumber bahan baku, proses manufaktur, pengiriman produk akhir kepada konsumen, serta pengelolaan produk setelah habis masa pakainya (Toke et al. 2010). Sehingga dapat disimpulkan konsep dari tata kelola yang peduli lingkungan ini didasarkan pada perspektif lingkungan, yaitu bagaimana mengurangi limbah dan dampak lingkungan yang diakibatkan oleh kegiatan rantai pasok. Hal ini merupakan aspek non finansial jangka panjang penting terkait dengan lingkungan yang harus diperhatikan oleh perusahaan dalam menjaga hubungan baik demi keberlanjutan kegiatan rantai pasoknya di masa yang akan datang. Dengan menerapkan GSCM, perusahaan dapat memperbaiki kinerjanya dengan memenuhi peraturan lingkungan, serta melakukan pengolahan kembali terhadap produk yang telah terpakai (Srivastava, 2007). Perusahaan memiliki beragam alasan untuk menerapkannya mulai dari sekedar kebijakan yang bersifat reaktif hingga pendekatan yang bersifat proaktif untuk mendapatkan keunggulan kompetitif yaitu meningkatkan daya saingnya melalui peningkatan kinerja finansial dan kinerja lingkungan (Pishvaee \& Razmi, 2012).

Kinerja lingkungan merupakan salah satu kinerja perusahaan yang bertujuan untuk memperbaiki atau mengurangi dampak kerusakan lingkungan yang diakibatkan oleh perusahaan. Semakin banyak kontribusi perusahaan terhadap lingkungan maka citra perusahaan di mata masyarakat semakin baik. Suatu perusahaan yang mempunyai kinerja lingkungan yang baik dan mengungkapkan kinerja lingkungannya dapat mempengaruhi pandangan investor terhadap perusahaan tersebut, yang nantinya akan dapat mempengaruhi kinerja keuangan/ finansial perusahaan. Kinerja keuangan merupakan salah satu faktor yang dapat menunjukkan keberhasilan perusahaan dalam mencapai tujuannya. Kinerja keuangan adalah kemampuan manajemen dalam mencapai prestasi dalam kinerjanya. Kondisi keuangan perusahaan dan gambaran kinerja keuangan dapat dilihat melalui laporan keuangan.

Kepedulian perusahaan terhadap lingkungan dapat dilakukan dengan mengurangi limbah yang diakibatkan oleh proses operasi rantai pasok. Berdasarkan organisasi Zero Waste, limbah merupakan indikator adanya ketidak efisiensian pada suatu perusahaan atau bisa disebut juga sumber daya yang tersembunyi. Sehingga dengan meminimasi limbah yang ada maka sebuah perusahaan dapat melakukan penghematan pada biaya. Pendekatan yang digunakan oleh organisasi Zero Waste adalah dengan menggunakan pendekatan closingthe-loop, sehingga seluruh bahan baku yang digunakan merupakan produk yang telah digunakan oleh konsumen. Limbah yang diungkapkan oleh organisasi ini dibagi menjadi lima, yaitu (a) Zero emissions (udara, tanah, air, limbah padat, limbah beracun), (b) Zero waste of resources (energi, bahan baku, manusia), (c) Zero waste in activities (administrasi, produksi), (d) Zero use of toxic (proses dan produk), (e) Zero waste in product life-cycle (transportasi, penggunaan, batas umur produk). Dari permasalahan yang ada terkait dengan pencemaran lingkungan maka penelitian ini dilakukan dengan membuat model Green Supply Chain Management untuk mengurangi waste dan melihat dampaknya terhadap kinerja lingkungan dan kinerja kuangan pada sektor restoran.

Beberapa penelitian terkait dengan green supply chain telah banyak dilakukan. Chiu \& Hsieh (2015) pada penelitiannya tentang The Impact of Restaurants' Green Supply Chain Practices on Firm Performance mengungkapkan bahwa Pemasok ramah Lingkungan memberikan kontribusi tinggi pada kinerja organisasi. Vel (2016) pada risetnya tentang The Impact of 
Implementing Green Supply Chain Anagement Practices on Corporate Performance mendapatkan bahwa hanya pembelian hijau yang berperan dalam memperbaiki kinerja ekonomi. Ghosh (2017) pada artikel riset tentang Green Supply Chain Management in Production Sectors and its Impact on Firm Reputation mendapatkan temuan serupa dengan peneliti sebelumnya bahwa implementasi green supply chain berpengaruh terhadap kinerka keuangan. Berdasarkan beberapa penelitian tersebut maka dirumuskan hipotesis 1: Green supply chain management berpengaruh terhadap kinerja finansial.

Selanjutnya, Puryono et al. (2016) pada risetnya tentang Penerapan Green Supply Chain Management Untuk Peningkatan performa Perusahaan menemukan bahwa GSCM (pengadaan, produksi, pengiriman dan pengembalian) berdampak terhadap Kinerja keuangan. Bahri \& Cahyani (2016) pada penelitiannya tentang Pengaruh Kinerja Lingkungan Terhadap Corporate Finansial Performance dengan Corporate Social Responsibility Disclosure sebagai Variabel Intervening menemukan bahwa kinerja lingkungan berpengaruh terhadap kinerja keuangan secara langsung. Shukla (2017) pada penelitiannya tentang Green Supply Chain Management: An Empirical Investigation on The Construction Sector. Berdasarkan beberapa penelitian ini maka dapat dirumuskan hipotesis 2: Green supply chain berpengaruh terhadap kinerja lingkungan.

Beberapa penelitian terkait kinerja lingkungan dengan kinerja finansial terungkap pada pendapat Sarumpet (2005) pada artikel The Relationship between Environmental Performance and Finansial Performance of Indonesian Companies menyatakan bahwa kinerja lingkungan berpengaruh terhadap kinerja keuangan. Purnomo \& Widianingsih (2012) pada artikelnya The Influence of Environmental Performance on Finansial Performance with Corporate Social Responsibility (CSR) Disclosure as a Moderating Variable: Evidence from Listed Companies in
Indonesia mendapatkan bahwa kinerja lingkungan berpengaruh terhadap kinerja finansial. Kemudian, Manrique \& Ballester (2017) pada artikelnya Analyzing the Effect of Corporate Environmental Performance on Corporate Finansial Performance in Developed and Developing Countries juga mengungkapkan bahwa kinerja lingkungan berdampak pada kinerja keuangan. Berdasarkan beberapa penelitian tersebut maka rumusan hipotesis 3: Kinerja lingkungan berpengaruh terhadap kinerja finansial.

Penelitian terkait green supply chain, kinerja lingkungan dan kinerja finansial terungkap pada Diab (2015) pada artikel risetnya The Impact of Green Supply Chain Management Practices on Organizational Performance: A Study of Jordanian Food Industries mendapatkan bahwa kinerja lingkungan yang baik sebagai dampak green supply chain berpengaruh terhadap kinerja finansial. Caniëls et all (2016) pada artikel risetnya tentang Implementing Green Supply Chain Practices: An Empirical Investigation In The Shipbuilding Industry mengungkapkan bahwa green supply chain berpengaruh pada kinerja lingkungan dan mendorong kinerja finansial. Juga Kim \& Chai (2017) pada hasil risetnya tentang Implementing Environmental Practices for Accomplishing Sustainable Green Supply Chain Management menegaskan bahwa kinerja lingkungan sebagai dampak implementasi green supply chain memediasi kinerja keuangan. Berdasarkan beberapa temuan penelitian tersebut maka dapat dirumuskan hipotesis 4: Kinerja lingkungan menjadi pemediasi pengaruh green supply chain terhadap kinerja finansial.

\section{METODE PENELITIAN}

Penelitian ini bersifat eksploratif dengan teknik survey sebagai alat pengumpul data. Variabel eksogen pada penelitian ini adalah Green Supply Chain Management. Menurut Srivastava (2007), GSCM merupakan pengintegrasian pemikiran lingkungan ke dalam supply chain management, termasuk desain produk, 
pembelian material dan seleksi pemasok, proses manufaktur, pengiriman produk akhir ke konsumen dan juga pengelolaan produk setelah masa manfaatnya. Adapun indikatornya menurut Ninlawan et al (2010) adalah green procurement, green process, green distribution, green logistic. Variabel mediasi dalam penelitian ini adalah Kinerja Lingkungan. Menurut Suratno et al. (2006), Kinerja lingkungan merupakan kinerja perusahaan dalam menciptakan lingkungan yang baik atau ramah lingkungan. Adapun indikator kinerja lingkungan menurut $\mathrm{Zhu}$ et al. (2008), adalah emisi udara, limbah cair, limbah padat, bahan berbahaya dan beracun, kecelakaan lingkungan. Sedangkan variabel endogen pada penelitian ini adalah kinerja keuangan. Menurut (Delen et al., 2013), kinerja keuangan merupakan usaha formal yang dilakukan perusahaan untuk dapat mengukur keberhasilan perusahaan dalam menghasilkan laba, sehingga dapat melihat prospek, pertumbuhan, dan potensi perkembangan perusahaan dengan mengandalkan sumber daya yang ada. Indikator kinerja finansial menurut Puryono et al. (2016) adalah pendapatan, biaya dan asset. Populasi pada penelitian ini adalah semua restoran di Kota Malang yang berjumlah 14 unit restoran dengan Kategori Selaka (Disperindag Kota Malang, 2017). Teknik pengambilan sampel adalah proporsional random sampling dengan menggunakan kuesioner sebagai alat pengumpul data dengan responden sebanyak 70 orang. Teknik analisis data menggunakan Partial Least Square.

\section{HASIL DAN PEMBAHASAN}

Pengujian model pengukuran dilakukan untuk menilai validitas dan reliabilitas model yang dilakukan dengan convergent validity, discriminant validity, dan composite reliability. Convergent validity bertujuan untuk mengukur kesesuaian antara indikator hasil pengukuran variabel dan konsep teoritis yang menjelaskan keberadaan-keberadaan indikator dari variabel tersebut. Uji convergent validity dapat dievaluasi dalam tiga tahap yaitu dengan melihat outer loadings, composite realibility dan Average Variance Extracted (AVE). Outer loadings adalah tabel yang berisi loading factor untuk menunjukkan besar korelasi antara indikator dengan variabel laten. Loading factor dapat diterima validitasnya jika nilainya $>0,60$. Untuk memudahkan dalam melihat outer loading dari blok-blok indikator yang mengukur konstruk maka disajikan hasil analisis diagram jalur pada gambar 1 berikut.

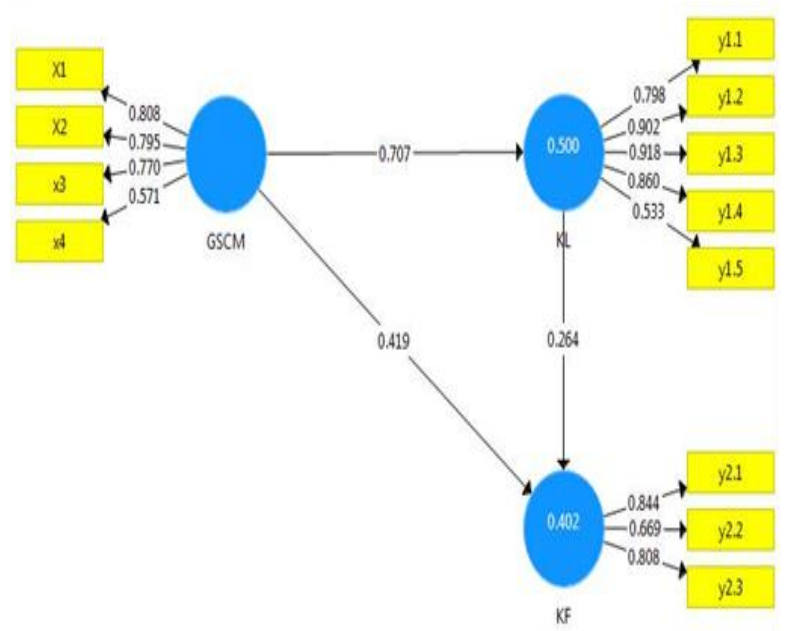

Gambar 1. Diagram Jalur Hasil Estimasi Pertama Sumber: Data Primer Diolah, 2018

Berdasarkan gambar 1, ternyata loading factor beberapa indikator tidak valid karena mempunyai koefisien dibawah 0,60. Indikator yang tidak valid tersebut adalah $\mathrm{x} 4$ $(0,571)$ dan y1.5 $(0,533)$ sehingga indikatorindikator tersebut harus dikeluarkan dari model. Penghapusan indikator nantinya dilanjutkan dengan melakukan estimasi ulang atau re-estimasi. Re-estimasi untuk evaluasi model pengukuran dimaksudkan untuk memeriksa kembali validitas loading factor setiap indikator. Jika uji validitas dengan outer loadings telah terpenuhi, maka model pengukuran mempunyai potensi untuk diuji lebih lanjut. Hasil re-estimasi disajikan dalam diagram jalur model pengukuran pada gambar 2 sebagai berikut. 


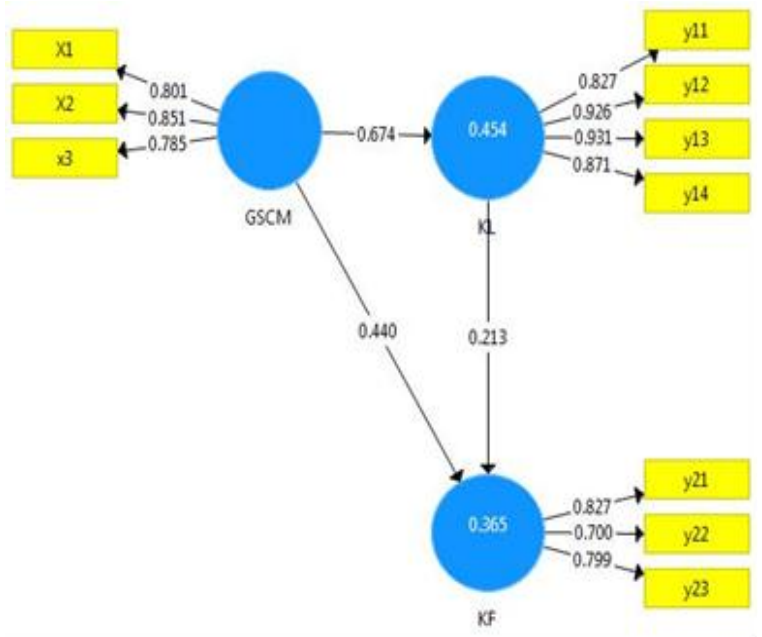

Gambar 2. Diagram Jalur Hasil Re-estimasi Sumber: Data Primer Diolah, 2018

Dari gambar 2 terungkap bahwa besaran loading factor hasil reestimasi dari masing-masing indikator yang mengukur konstruk. Hasil reestimasi tersebut menunjukkan bahwa seluruh indikator telah memiliki validitas yang baik karena memiliki loading factor lebih dari 0,70. Selanjutnya adalah convergent validiy dengan mengukur nilai AVE, dapat dilihat pada tabel 1 dibawah ini.

Tabel 1. Average Variance Extracted (AVE).

\begin{tabular}{ll}
\hline Variabel & AVE \\
\hline GSCM & 0,661 \\
KF & 0,604 \\
KL & 0,792
\end{tabular}

Sumber : Hasil Analisis Data Primer, 2018

Berdasarkan tabel 1 terungkap bahwa hasil pengujian nilai AVE untuk konstruk green supply chain management, kinerja lingkungan, kinerja finansial masing-masing adalah 0,$661 ; 0,604 ; 0,792$ lebih besar dari 0,50, maka semua konstruk telah memenuhi uji validitas konvergen. Sehingga disimpulkan, indikator-indikator tersebut dinyatakan vaid dan dapat diterima sebagai pengukur variabel laten penelitian. Selanjutnya, pengujian validitas diskriminan dilakukan untuk membuktikan apakah indikator pada suatu konstruk akan mempunyai loading factor terbesar pada konstruk yang dibentuknya dari pada loading factor dengan konstruk yang lain. Hal itu dapat dilihat cross loading pada tabel 2 . Nilai pada tabel 2, menunjukkan bahwa validitas deskriminan cukup baik, karena nilai korelasi indikator terhadap konstruknya lebih tinggi dibandingkan nilai korelasi indikator terhadap konstruk lainnya.

Sebagai ilustrasi loading factor $\mathrm{X}_{1}$ (indikator pertanyaan untuk green supply chain management) adalah sebesar 0,801. Nilai tersebut lebih tinggi daripada loading factor dengan konstruk lain yaitu $\operatorname{KL}(0,458)$ dan KF (0,565). Tabel tersebut juga menunjukkan bahwa indikator kinerja lingkungan dan kinerja finansial juga mempunyai nilai loading factor lebih tinggi dari loading factor konstruk yang lain. Dengan demikian, konstruk laten memprediksi indikator pada blok yang lebih baik dibandingkan dengan indikator di blok lain.

Tabel 2. Cross Loading Factors

\begin{tabular}{|c|c|c|c|}
\hline & GSCM & KL & KF \\
\hline X1 & 0,801 & 0,458 & 0,565 \\
\hline $\mathrm{X} 2$ & 0,851 & 0,676 & 0,424 \\
\hline X3 & 0,785 & 0,496 & 0,438 \\
\hline Y1.1 & 0,629 & 0,827 & 0,388 \\
\hline Y1.2 & 0,590 & 0,926 & 0,431 \\
\hline Y1.3 & 0,579 & 0,931 & 0,536 \\
\hline Y1.4 & 0,599 & 0,871 & 0,452 \\
\hline Y2.1 & 0,466 & 0,557 & 0,827 \\
\hline Y 2.2 & 0,511 & 0,246 & 0,700 \\
\hline Y2.3 & 0,368 & 0,351 & 0,799 \\
\hline
\end{tabular}

Selanjutnya, untuk uji kekonsistenan indikator-indikator dalam satu variabel laten dilakukan dengan uji reliabilitas. Uji reliabilitas dapat diukur dari nilai cronbach's alpha dan nilai composite reliabilitas. Untuk dapat dinyatakan suatu konstruk reliabel, maka nilai cronbach's alpha harus lebih dari 0,6 dan nilai composite reliability harus lebih dari 0,70 . 
Tabel 3. Hasil Cronbach's Alpha dan Composite Reliability

\begin{tabular}{ccc}
\hline Variabel & $\begin{array}{c}\text { Cronbach } \\
\text { 's Alpha }\end{array}$ & $\begin{array}{c}\text { Composite } \\
\text { Reliability }\end{array}$ \\
\hline GSCM & 0,744 & 0,854 \\
Kinerja Lingkungan & 0,911 & 0,820 \\
Kinerja Finansial & 0,671 & 0,938 \\
\hline
\end{tabular}

Sumber: Data Primer Diolah, 2018

Kemudian, inner model menggambarkan hubungan antar variabel laten berdasarkan pada teori substantif. Nilai $R$-square menunjukkan tingkat determinasi variabel eksogen terhadap endogennya. Nilai $R$ square semakin besar menunjukkan tingkat determinasi yang semakin baik. Nilai $R$ square sebesar 0,67 (kuat), 0,33 (moderat) dan 0,19 (lemah). Berikut hasil perhitungan dari $R$-square.

Tabel 4. Nilai $R$-square.

\begin{tabular}{lc}
\hline Variabel Endogen & $R$-square \\
\hline Kinerja Lingkungan & 0,365 \\
Kinerja Finansial & 0,454 \\
\hline Sumber: Data Primer Diolah, 2018 &
\end{tabular}

Hasil perhitungan $R$-square untuk setiap variabel laten endogen pada tabel 4 menunjukkan bahwa nilai $R$-square pada kinerja lingkungan sebesar 0,365 (Moderat) yang artinya variabel kinerja lingkungan dipengaruhi oleh variabel GSCM sebesar 0,365 atau 36,5\%. Selebihnya 63,5\% dipengaruhi oleh variabel lain. Nilai Rsquare pada variabel kineja finansial sebesar 0,454 (Moderat) yang artinya variabel kinerja finansial dipengaruhi oleh variabel GSCM sebesar 0,454 atau 45,5\%. Selebihnya $54,5 \%$ dipengaruhi oleh variabel lain. Dengan demikian, berdasarkan bebera hasil pengujian tersebut, maka model pengukuran semua variabel memiliki reliabilitas dan validitas yang baik dan dapat dilanjutkan pada pengujian hipotesis.

Dalam menguji hipotesis, penelitian ini menggunakan beberapa kriteria yang harus dipenuhi, yaitu original sampel, t-statistic, dan $p$-value. Nilai original sampel digunakan untuk melihat arah dari pengujian hipotesis, jika pada original sampel menunjukkan nilai positif berarti arahnya psitif, dan jika nilai original sampel negatif berarti arahnya negatif. Kemudian t-statistic digunakan untuk menunjukan signifikansi. Untuk pengujian menggunakan t-statistik maka harus diketahui apakah hipotesis memiliki arah atau tidak. Dalam penelitian ini nilai $t$ statistic yang dihasilkan dari output PLS dibandingkan dengan nilai t-tabel.

Kriteria pengujian dengan tingkat signifikansi $(\alpha)$ 5\% ditentuan apabila thitung>t-tabel, yaitu lebih dari 1,96 maka hipotesis diterima, sedangkan apabila $\mathrm{t}$ hitung $<\mathrm{t}$-tabel, yaitu kurang dari 1,96 maka hipotesis ditolak. Kemudian yang terakhir adalah $p$-value, kriteria ini digunakan juga untuk menguji signifikansi dari suatu hasil. Nilai $p$-value yang harus dicapai agar suatu hipotesis dapat diterima jika<0,05. Untuk dapat dinyatakan suatu hipotesis bisa diterima, maka ketiga kriteria tadi harus terpenuhi. Apabila salah satu atau lebih dari kriteria tersebut tidak terpenuhi, maka hipotesis ditolak. Berdasarkan hasil analisis data primer dengan menggunakan Partial Least Square (PLS) Versi 3, ditampilkan pada tabel 5.

Berdasarkan tabel 5 diketahui bahwa pengaruh green supply chain management (GSCM) terhadap kinerja finansial memiliki nilai original sampel sebesar 0,44 . Hipotesis 1 terdukung karena nilai $t$-statistic sebesar 2,24 lebih besar dari nilai t-tabel (tingkat signifikansi $5 \%=1,96)$ dan nilai $p$ value $<0,05$. Maknanya bahwa dengan menerapkan green supply chain management pada restoran di Kota Malang maka kinerja finansialnya akan mengalami peningkatan. Dengan demikian, maka rumusan hipotesis pertama pada penelitian ini dapat diterima.

Tabel 5. Ringkasan Hasil Uji Hipotesis

\begin{tabular}{lccccc}
\hline & $\begin{array}{c}\text { Orginal } \\
\text { Sample }\end{array}$ & $\begin{array}{c}\text { Sample } \\
\text { Mean }\end{array}$ & $\begin{array}{c}\text { Standard } \\
\text { Deviation }\end{array}$ & $\begin{array}{c}\text { T } \\
\text { Statistics }\end{array}$ & P \\
\hline $\begin{array}{l}\text { GSCM }- \\
>\text { KF }\end{array}$ & 0,440 & 0,448 & 0,196 & 2,243 & 0,025 \\
GSCM- & 0,674 & 0,681 & 0,058 & 11,656 & 0,000 \\
$>$ KL & & & & & \\
KL->KF & 0,213 & 0,211 & 0,177 & 1,204 & 0,229 \\
GSCM- & 0,143 & 0,138 & 0,131 & 1,097 & 0,273 \\
$>$ KL->KF & & & & & \\
\hline
\end{tabular}

Sumber: Data Primer Diolah, 2018 
Selanjutnya, hipotesis yang kedua menyatakan green supply chain management berpengaruh terhadap kinerja finansial. Berdasarkan tabel 5 diketahui bahwa pengaruh green supply chain management terhadap kinerja lingkungan mempunyai nilai original sample sebesar 0,674 dengan nilai $t$-statistic sebesar 11,65 yang berarti lebih besar dari nilai t-tabel (tingkat signifikansi $5 \%=1,96)$ dan nilai $\mathrm{P}$-value 0,000 kurang dari 0,05. Hal tersebut menunjukkan bahwa penerapan green supply chain management mempunyai pengaruh signifikan terhadap kinerja lingkungan pada restoran di kota Malang. Dengan demikian hipotesis kedua pada penelitian ini diterima.

Sedang hipotesis ketiga menyatakan bahwa kinerja lingkungan berpengaruh terhadap kinerja finansial pada restoran di Kota Malang. Berdasarkan tabel 5 terungkap bahwa nilai original sample sebesar 0,213 dengan nilai $t$-statistic sebesar 1,204 yang berarti kurang dari nilai t-tabel (tingkat signifikansi $5 \%=1,96)$ dan nilai $p$ value $>0,05$ yaitu sebesar 0,229 . Hal tersebut menunjukkan bahwa kinerja lingkungan pada restoran tidak mempunyai pengaruh terhadap kinerja finansial pada restoran di kota Malang. Dengan demikian hipotesis ketiga pada penelitian ini ditolak.

Hipotesis keempat menyatakan bahwa

Green Supply Chain Management berpengaruh secara tidak langsung terhadap kinerja finansial melalui kinerja lingkungan pada restoran di kota Malang. Tabel 5 menunjukkan bahwa berdasarkan hasil uji indirect effect diperoleh nilai $t$-statistic sebesar 1,097 yang berarti kurang dari nilai ttabel (tingkat signifikansi 5\%=1,96) dan nilai p-value lebih dari 0,05 yaitu sebesar 0,273. Dengan demikian hipotesis keempat dalam penelitian ini ditolak. Maknanya, kinerja lingkungan tidak memediasi pengaruh green supply chain terhadap kinerja finansial.

Selanjutnya, jika hasil uji hipotesishipotesis penelitian tersebut dibandingkan dengan temuan beberapa penelitian sebelumnya, maka tentu ada yang sejalan dan ada juga yang bertentangan. Berdasarkan hasil analisis terungkap bahwa hipotesis penelitian pertama yang mendapatkan bahwa green supply chain management berpengaruh signifikan terhadap kinerja finansial. Maknanya, semakin baik tata kelola green supply chain management maka semakin baik pula tingkat kinerja finansialnya. Temuan ini sejalan dengan pendapat Beamon (1999), bahwa diperkirakan $75 \%$ dari konsumen mengklaim bahwa daya beli dipengaruhi oleh penerapan GSCM pada restoran dan bahwa $80 \%$ akan bersedia membayar lebih untuk barang ramah lingkungan. Selain itu, hasil penelitian ini juga sejalan dengan penelitian puryono et al, (2016) yang menyatakan bahwa dengan menerapkan GSCM perusahaan mengalami peningkatan performa keuangan sebesar $87,3 \%$ dan $12,7 \%$ perusahaan efisien. Selanjutnya, sejalan dengan penelitian Vel, (2016) yang menjelaskan bahwa green procurement berpengaruh positif dan sangat berperan dalam memperbaiki kinerja ekonomi perusahaan. Juga mendukung hasil riset Ghosh (2017) bahwa green supply chain berpengaruh pada kinerja finansial.

Selanjutnya, hasil analisis lain juga menunjukkan bahwa hipotesis penelitian kedua, yaitu: green supply chain management berpengaruh signifikan terhadap kinerja lingkungan. Temuan ini membuktikan bahwa green supply chain management penting dalam sebuah restoran untuk meningkatkan kinerja lingkungan pada restoran khusunya di Kota Malang. Semakin baik tata kelola green supply chain management maka semakin baik pula tingkat kinerja lingkungan atau tingkat kepedulian restoran pada lingkungan sekitarnya. Green supply chain management (GSCM) akan menjadi sebuah rantai pasok yang ramah lingkungan bertujuan membatasi limbah dalam restoran dam mencegah disipasi limbah bahan berbahaya dan beracun (limbah B3) ke lingkungan. Penelitian ini sejalan dengan penelitian Shukla (2017) yang menyatakan bahwa dengan menerapkan GSCM telah memberi dampak positif pada kinerja lingkungan, ekonomi dan organisasi bagi pemangku kepentingan. Selain itu mendukung hasil penelitian Jun-Zhi Chiu \& 
Chao-Chen (2014) dan Hsieh, (2015) yang menjelaskan bahwa green procurement dalam GSCM memberikan kontribusi tinggi pada kinerja organisasi yaitu kinerja lingkungan.

Hipotesis penelitian yang ketiga ini menunjukkan bahwa kinerja lingkungan tidak berpengaruh terhadap kinerja finansial. Penelitian ini bertentangan dengan penelitian Bahri \& Cahyani, (2016) yang menyatakan bahwa kinerja lingkungan berpengaruh terhadap kinerja finansial secara langsung. Hasil tersebut menunjukkan bahwa informasi yang telah dikeluarkan oleh Kementrian Lingkungan Hidup mengenai kinerja lingkungan tidak dapat mempengaruhi kinerja finansial. Walaupun perusahaan atau restoran telah melakukan upaya pengelolaan lingkungan yang dipersyaratkan seperti yang diatur dalam perundang-undangan tidak menjamin bahwa kinerja keuangan perusahaan akan meningkat. Hal ini disebabkan karena kualitas atau kuantitas pelayanan yang belum sesuai dengan harapan masyarakat atau konsumen, selain itu restoran yang belum peduli terhadap kelestarian lingkungan dan kesejahteraan masyarakat disekitar menyebabkan restoran tersebut mendapat image negatif dari masyarakat atau konsumen. Hal ini berdampak tidak meningkatnya kinerja finansial pada restoran. Image positif restoran itu sangat penting untuk keberlangsungan restoran, oleh karena itu restoran harus berusaha keras untuk mendapatkan legitimasi yang baik dari masyarakat atau konsumen agar bisa mendapatkan image positif. Jika restoran telah mendapatkan legitimasi yang baik dari masyarakat atau konsumen maka restoran akan mendapatkan image positif yang akan meningkatkan kinerja restoran secara finansial.

Hasil analisis yang hipotesis keempat bahwa kinerja lingkungan tidak mampu menjadi variabel mediasi pada pengaruh green supply chain management dengan kinerja finansial. Hasil penelitian ini tidak sejalan dengan penelitian Shukla, (2017) yang menyatakan bahwa dengan menerapkan
GSCM telah memberi dampak positif pada kinerja lingkungan, ekonomi (finansial) dan organisasi bagi pemangku kepentingan. Dari analisis jalur yang telah dilakukan menunjukkan bahwa kinerja lingkungan berpengaruh secara signifikan dengan green supply chain management (GSCM) namun tidak memiliki pengaruh signifikan terhadap kinerja finansial, maka kinerja lingkungan bukan merupakan variabel mediasi yang terletak diantara variabel independen dan variabel dependen, sehingga variabel independen tidak langsung mempengaruhi berubahnya atau timbulnya variabel dependen (Sugiyono,2008). Oleh karena itu hipotesis keempat yang menyatakan bahwa green supply chain management tidak berpengaruh terhadap kinerja finansial dengan kinerja lingkungan sebagai variabel mediasi ditolak juga bertentangan dengan pendapat Kim \& Chai (2017) pada hasil riset yang dilakukan tentang Implementing Environmental Practices for Accomplishing Sustainable Green Supply Chain Management.

Temuan empirik tersebut menunjukkan bahwa kesadaran lingkungan pelaku usaha di Indonesia terhadap restoran atau usahanya masih rendah dikarenakan masih banyaknya oknum-oknum yang membuang limbah restoran sembarangan dan tidak memperhatikan dampak dari lingkungan sekitarnya. Hal tersebut sangat berbanding terbalik dengan negara lain seperti Taiwan. Kesadaran lingkungan pelaku usaha sangat tinggi. Setiap limbah yang dihasilkan dari industri maupun rumah tangga selalu di olah atau didaur ulang agar tidak mencemari lingkungan serta mereka juga mampu mengubah konsep ruangan atau industri menjadi ramah lingkungan dan terlihat green. Ketika suatu restoran mampu meningkatkan kinerja lingkungan, dampaknya restoran dapat meningkatkan brand image atas kepedulian terhadap lingkungan serta meningkatkan marketing strategic. Meskipun dalam beberapa kasus, biaya green supply chain management (GSCM) lebih tinggi namun di lain sisi dapat menciptakan brand image perusahaan atas kepedulian 
pada lingkungan sehingga pada gilirannya dapat meningkatkan daya saing unik bagi restoran

\section{Kesimpulan}

Berdasarkan hasil penelitian mengenai green supply chain management, kinerja lingkungan dan kinerja finansial pada restoran yang ada di Kota Malang yang memiliki golongan Selaka dan Gangsa dapat ditarik kesimpulan: 1) green supply chain management mempunyai pengaruh terhadap kinerja finansial. Hal ini menunjukkan bahwa tata kelola green supply chain management penting dalam sebuah restoran untuk meningkatkan kinerja finansial restoran khususnya di Kota Malang. Semakin baik green supply chain management diterapkan, maka semakin tinggi pula tingkat kinerja finansial; 2) green supply chain management mempunyai pengaruh terhadap kinerja lingkungan. Hal ini menunjukkan bahwa tata kelola green supply chain management (GSCM) penting dalam sebuah restoran untuk meningkatkan kinerja lingkungan pada restoran khusunya di Kota Malang. Semakin baik green supply chain management maka semakin tinggi pula tingkat kinerja lingkungan atau tingkat kepedulian restoran pada lingkungan sekitarnya; 3) kinerja lingkungan tidak mempunyai pengaruh terhadap kinerja finansial. Hal ini menunjukkan bahwa kinerja lingkungan tidak dapat mempengaruhi kinerja finansial walaupun restoran telah melakukan upaya pengelolaan dibidang lingkungan yang dipersyaratkan sebagaimana diatur dalam perundangundangan tidak menjamin bahwa kinerja keuangan perusahaan akan meningkat. Hal ini disebabkan karena kualitas atau kuantitas pelayanan belum sesuai dengan harapan masyarakat atau konsumen; 4) kinerja lingkungan tidak mampu menjadi variabel mediasi antara pengaruh green supply chain management dengan kinerja finansial. Hal ini menunjukkan bahwa kesadaran lingkungan pelaku usaha di Indonesia terhadap restoran atau usahanya masih rendah, sangat berbanding terbalik dengan negara lain seperti Taiwan. Kesadaran lingkungan pelaku usaha sangat tinggi. Setiap limbah yang dihasilkan dari industri maupun rumah tangga selalu di olah atau di daur ulang agar tidak mencemari lingkungan sekitarnya. Ketika suatu restoran mampu meningkatkan kinerja lingkungan, dampaknya restoran dapat meningkatkan brand image atas kepedulian terhadap lingkungan serta meningkatkan marketing strategic sehingga dapat meningkatkan daya saing unik bagi restoran. Selanjutnya, temuan penelitian yang mendapatkan bahwa kinerja lingkungan tidak berpengaruh terhadap kinerja finansial hendaknya dapat menjadi inspirasi bagi para peneliti lain untuk melakukan penelitian lanjutan mengingat hal ini paradoks dengan logika teoritik.

\section{DAFTAR PUSTAKA}

Agus Indrio, Gitusudarmo. Basri. (2002). Manajemen Keuangan. BPFE. Yogyakarta

Anwar, Sariyun Naja. (2013), Manajemen Rantai Pasokan (Supply Chain Management): Konsep dan Hakikat. Jurnal Ekonomi. 1(4):16-24.

Arikunto, Suharsimi.1993. Prosedur Penelitian Suatu Pendekatan Praktek. Rineka Cipta. Jakarta.

Bastian, Indra. 2006. Akuntansi Sektor Publik: Suatu Pengantar Erlangga. Jakarta.

Beamon, B.M., 1999, Measuring Supply chain Performance, International Journal of Operation and Production Management, 5(3): 126-138

Bloemhuf-Ruwaard, J.M., P. van Beck, L. Hordijk, dan L.N. van Wassenhove. (1995) Interactions between operational and environmental management. 1995. European Journal of Operational Research. 8(5): 25-35.

Caniëls et all (2016), Implementing green supply chain practices: an empirical investigation in the shipbuilding industry, Mritime Policy \& Management Journal, 43(8): 1005-1020. 
Delen, D., Kuzey, C. \& Uyar, A.. 2013. Measuring Firm Performance Using Finansial Aatios : A Decision Tree Approach. Expert Systems With Applications.

Dheeraj. Namdev, Vishal. An Overview of Green Supply Chain Management in India. 2012. Research Journal of Recent Sciences. 1(6): 70-82.

Diab et all (2015), The Impact of Green Supply Chain Management Practices on Organizational Performance: A Study of Jordanian Food Industries, Journal of Management and Sustainability; 5(1): 149-157.

Ferdinand. 2013. Metode Penelitian Manajemen: Pedoman Penelitian untuk skripsi, Tesis dan Disertai Ilmu Manajemen. Semarang: Universitas Diponegoro.

Fleury, Davies. 2012. Sustainable supply chains - minerals and sustainable development, going beyond the mine. Resource Policy 37.

Gilbert, S. 2000. Greening supply chain: Enhancing competitiveness through green productivity.Tokyo: Asian Productivity Organization.

Ghozali, Imam, 2011, Structural Equation Modeling Metode Alternatif Dengan Partial Least Square (PLS) Edisi 3, Badan Penerbit Universitas Diponegoro. Semarang.

Handfield. Nichols. 2002. Supply chain redesign: Transforming supply chains into integrated value systems. New Jersey: Finansial Times Prentice Hall.

Ikhsan, Arfan. 2008. Akuntansi Lingkungan dan Pengungkapannya. Graha ilmu Yogyakarta.

Indrajit, R.E. Pranoto, R. D. 2005. Konsep manajemen suplly chain: cara baru memandang rantai penyediaan barang. Grasindo. Jakarta.

Kim, M. \& Chai, S. (2017), Implementing Environmental Practices for Accomplishing Sustainable Green Supply Chain Management, Sustainability Journal,9: 1-17
Kurien, G.P et al. Performance measurement systems for green supply chains using modified balanced score card and analytical hierarchical process. 2012. Academic Journals. 36(10): 101-112.

Lankoski, Leena. 2000. Determinants of Environmental Profit. An Analysis of the Firm-Level Relationship Between Environmental Performance and Economic Performance. Helsinki University of Technology.I

Manrique S.\& Ballester, C.P.M. (2017), Analyzing the Effect of Corporate Environmental Performance on Corporate Finansial Performance in Developed and Developing Countries, Journal of Sustainability, 9: 1-30.

Ninlawan, C. Seksan, P. Tossapol, K. Pilada, W. 2010, The Implementation of Green Supply Chain Management Practices in Electronics Industry. Proceeding of the International Multi Converence of Engineers and Computer Scientists, 3:210-220.

Noor, Juliansyah. 2012. Metodologi Penelitian. Kencana Prenada Media Group. Jakarta.

Nurhasanah. 2009. Penentuan Kadar COD (Chemical Oxygen Demand) pada Limbah Cair Pabrik Kelapa Sawit, Pabrik Karet dan Domestik. Medan : Universitas Sumatera Utara.Padil, dkk. 2006. Pembuatan Arang Aktif dari Sisa Pembuatan Asap Cair. Pekanbaru : Universitas Riau.

Purnomo, P.K. \& Widianingsih, L.P. (2012) pada artikelnya The Influence of Environmental Performance on Finansial Performance with Corporate Social Responsibility (CSR) Disclosure as a Moderating Variable: Evidence from Listed Companies in Indonesia, Rev. Integr. Bus. Econ. Res. 1(1): 57-69.

Pishvaee, M.S. Razmi, J. 2012. Environmental Supply Chain Network Design Using Multi Objective Fuzzy Mathematical Programming. Applied Mathematical Modelling. 
Penfield, P. 2007. Sustainability can be competitive advantage. Whitman School of Management.

Peraturan Pemerintah Nomor 27 Tahun 2012 Tentang Izin Lingkungan.

Presiden republik Indonesia. Keputusan Presiden No.74 Tahun 2001 tentang Tata Cara Pengawasan Penyelenggaraan Peraturan Daerah.

Purnomo, Agus. Penentuan Rute Pengiriman Menggunakan metode Clark and Wright Heuristic (stusi kasus di PT Teh Botol Sosro Bandung). 2010. Jurnal Logistik Bisnis Politeknik Pos Indonesia. 1(2): 97- 117.

Puryono, Daniel. Mustafid. Jie, Ferry. Penerapan Green Supply Chain Management Untuk Peningkatan Kinerja Keuangan Perusahaan. 2016. Journal Sistem Informasi Bisnis 2:65-76.

Sarumpet, S. (2005), The Relationship between Environmental Performance and Finansial Performance of Indonesian companies, Jurnal Akuntansi \& Keuangan, 7(2): 89-98.

S. Munawir. 2007. Analisis Laporan Keuangan Edisi Empat. PT. Liberty. Yogyakarta. Simchi-Levi et al. 2000. Designing and Managing the Supply Chain: Concepts, Strategies and Case Studies. McGraw-Hill International Edition. Singapore.

Srivastava, S.K. Green Supply-Chain Management: A State-Of-The-Art Literature Review. 2007. International Journal of Management Reviews. 9: 5380.

Suharto, Ign. 2011. Limbah Kimia dalam Pencemaran Air dan Udara. CV. Andi Offset. Yogyakarta.

Sundarakani, B. Souza R. Goh, M. 2010. Modelling Carbon Footprints Across The Supply Chain. Internasional Journal Production Economics. 128: 4350.

Suratno, Darsono, dan Siti Mutmainah. 2006. Pengaruh Environmental Performance Terhadap Environmental Disclosure Dan Economic Performance: Studi Empiris Pada Perusahaan Manufaktur Yang
Terdaftar Di Bursa Efek Jakarta Periode 2001-2004. SNA IX Padang. 23-26 Agustus.

Tobing, B. 2015. Rantai Pasok Produk Pangan (Food Supply Chain), http://supplychainindonesia.com/new/ra ntai-pasok-pangan-food supplychain/. online accessed on 26 oktober 2016.

Toke, L,K.. R, C, Gupta. Milind Dandekar. 2010. Green Supply Chain Management; Critical Research and Practices. Proceedings of the 2010 International Conference on Industrial Engineering and Operations Management. Dhaka, Bangladesh.

Vincenzo et,.al. (2010). Handbook of Partial Least Square. Springer-Verlag Berlin Heidelberg

Zhu, Q. Sarkis J. Lai K.. Initiatives And Outcomes Of Green Supply Chain Management Implementation by Chinese Manufacturers. Journal of Environmental Management 8(5):11-23. 